\title{
O que é ser saudável? Entre publicidades modernas e contemporâneas
}

Paula Sibilia

Marianna Ferreira Jorge

Resumo: O objetivo deste artigo consiste em examinar os modos pelos quais se manifesta a "medicalização da vida" em discursos midiáticos, com o intuito de identificar suas implicações na produção de subjetividades. Parte-se da hipótese de que estaria ocorrendo um deslocamento nas definições de saúde e normalidade. Além da discussão teórica, serão analisadas publicidades voltadas para a saúde - seja através de avisos comerciais ou matérias jornalísticas - desde o início do século XX até hoje.

Palavras-chave: medicalização; subjetividade; saúde; doença; publicidade.

Abstract: What means to be healthy? Between modern and contemporary advertising - The goal of this paper is to examine the different ways the "medicalization of life" appears in media speeches, in order to identify its implications for the production of subjectivities. The starting hypothesis is that there is a current shift in the definitions of healthiness and normality. Besides the theoretical discussion, we proceed to the analysis of advertisements and journalistic pieces that encompass health subjects dating from the beginning of the 20th century until now.

Keywords: medicalization; subjectivity; health; disease; advertising.

\section{Introdução}

As vidas humanas são constituídas pelos saberes e poderes que vigoram numa determinada época. Propõe-se, aqui, identificar algumas práticas - e sentidos a elas associadas - que são próprias da era atual, sobretudo no que concerne aos deslocamentos na noção de saúde. Na era moderna, a vida tornou-se o foco de todo um leque de novos poderes e saberes normalizadores: trata-se daquilo que Michel Foucault denominou biopolítica. 
Seus impulsos massificantes e totalizantes visaram, a partir do século XVIII, moldar as potências vitais com o objetivo de garantir o planejamento, a regulação e a prevenção das populações em diversos segmentos, impondo-lhes certas normas a serviço dos interesses que guiavam os projetos nacionais e industriais da época. Seu foco pretendia controlar processos biológicos, tais como a saúde, a higiene, a natalidade, a longevidade e a raça.

A normalização dos sujeitos tornou-se a principal finalidade desse tipo de poder atuante nas sociedades ocidentais da era moderna. Com a ajuda dos rudimentos tecnocientíficos então vigentes, cabia às instituições da época, como a escola, a fábrica, a prisão e o hospital - através de estratégias como o exame, a confissão e a observação - o papel de hierarquizar, diagnosticar e classificar os indivíduos. A intenção era homogeneizá-los e estabelecer fronteiras bem definidas entre aqueles cujo comportamento se considerava normal e os anormais ou desviantes. Para isso, contava-se com o valioso suporte das ciências humanas e sociais, incluindo os instrumentos de cálculos estatísticos e demográficos, que possibilitaram uma maior compreensão e certo controle sobre as doenças, além da aplicação de regulamentações sanitárias.

Contudo, as políticas de higienização e planejamento urbano, até então inéditas, foram vistas com estranhamento pelas populações da época, e tiveram que ser implementadas com certa violência sobre o corpo social. Isso desencadeou muitas resistências, tais como a "revolta da vacina" ocorrida no Rio de Janeiro em 1904.

\section{Corrigir doenças para normalizar a vida}

A medicina que se configurou a partir dos séculos XVIII e XIX, portanto, propôs-se a dominar as aleatoriedades relativas aos fatores orgânicos e biológicos dos seres humanos, combatendo as patologias para manter a vida. Nesse contexto, a maioria da população era considerada "normal", pois para ser saudável bastava ter uma sensação básica de vitalidade e a ausência de sintomas de qualquer doença. Já a preocupação com a saúde, só fazia sentido ao se manifestar alguma enfermidade. Ainda assim, no final do século XIX, as companhias farmacêuticas já eram anunciantes publicitárias bem-sucedidas, sendo as clientes das agências de propaganda que mais investiam para disseminar seus produtos (VAZ e PORTUGAL, 2012). Através de variadas estratégias mercadológicas, elas prometiam revitalizar os corpos curando doenças e possibilitando o retorno dos enfermos ao sistema produtivo, conforme ilustra a propaganda abaixo [Figura 1], de 1919: 


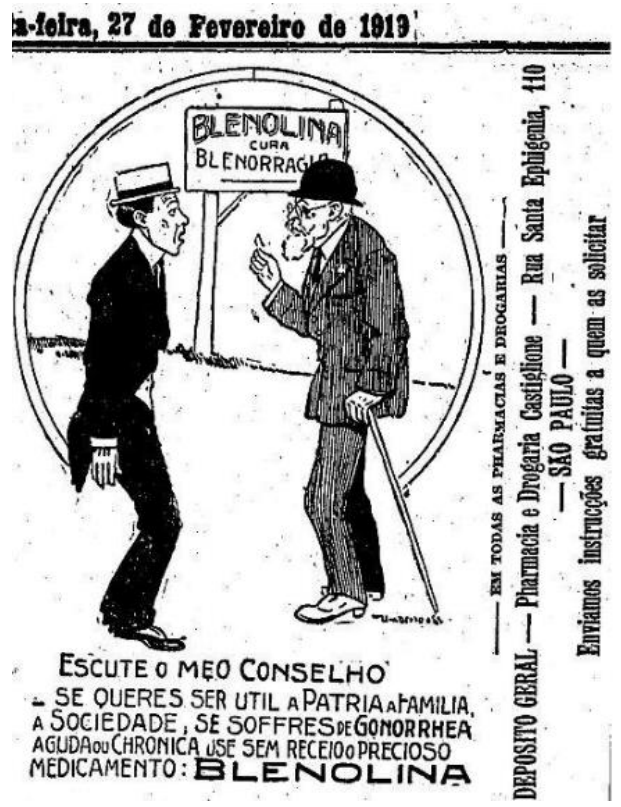

Fig.1. Estado de S. Paulo, 1919

Indo ao encontro dessas estratégias biopolíticas, cabe citar outro exemplo: o do personagem Jeca Tatu, de Monteiro Lobato. Em 1914, no Brasil, o escritor se indignava com as secas e as queimadas que assolavam o país. Por isso, resolveu escrever uma série de textos, publicados no jornal Folha de S. Paulo, com enorme repercussão nacional, nas quais fazia pesadas críticas àquela situação e reivindicava melhorias. Mas logo o autor resolveu ir além, mudando os rumos da história do seu já famoso personagem Jeca Tatu, que em sua versão original chegou a ser caracterizado por outro escritor contemporâneo dele, Rui Barbosa (apud PALMA, 2014), como "símbolo de preguiça e fatalismo, de sonolência e imprevisão, de esterilidade e tristeza, de subserviência e embotamento". Tais traços comportamentais, bem como a sua recusa ao trabalho, que até então eram tidos como características intrínsecas à sua personalidade, começaram a ser interpretados, pelo seu próprio autor, como sintomas de uma doença. A intenção dessa virada era impactar a sociedade estimulando mudanças nas condutas: tanto um maior cuidado de si por parte dos indivíduos, como pressões ao governo para a implementação de medidas sanitárias. Como primeiro passo dessa missão, Lobato escreveu em 1918 no prefácio à quarta edição de seu livro Urupês:

Eu ignorava que eras assim, meu caro Jeca, por motivo de doenças tremendas. Está provado que tens no sangue e nas tripas todo um jardim zoológico da pior espécie. É essa bicharia cruel que te faz papudo, feio, molenga, inerte. (LOBATO, 2014) 
Contudo, isso não bastava para causar o efeito desejado, pois o alcance da literatura se restringia às elites brasileiras, sem conseguir chegar ao público almejado: aqueles que eram as principais vítimas das precárias situações socioeconômicas e, além disso, as crianças em geral. Assim, a convite do laboratório Fontoura, responsável pelo remédio destinado a tratar a ancilostomíase - uma doença parasitária infecciosa conhecida popularmente como amarelão -, Lobato escreveu uma nova história para o personagem, intitulada Jeca Tatu: A ressureição, com distribuição nacional em forma de almanaque publicitário. O texto indicava os já famosos traços de sua personalidade como sendo os sintomas da doença em questão e, por fim, oferecia o remédio para curá-la. Nesse conto, o personagem que sempre foi considerado "preguiçoso, bêbado e idiota por todos", ao ser consultado pelo médico, descobre que o problema era que sofria de amarelão, como se constata nos trechos seguintes:

Jeca só queria beber pinga e espichar-se ao sol no terreiro. Ali ficava horas, com o cachorrinho rente; cochilando [...] Jeca não queria saber de nada. Trabalhar não era com ele.

Um dia um doutor portou lá por causa da chuva e espantou-se de tanta miséria. Vendo o caboclo tão amarelo e chucro, resolveu examiná-lo.

- Amigo Jeca, o que você tem é doença.

- Pode ser. Sinto uma canseira sem fim, e dor de cabeça, e uma pontada aqui no peito que responde na cacunda.

- Isso mesmo. Você sofre de anquilostomiase.

[...] Jeca ficou cismando. Não acreditava muito nas palavras da ciência, mas por fim resolveu comprar os remédios, e também um par de botinas ringideiras [...] Quando o doutor reapareceu, Jeca estava bem melhor, graças ao remédio tomado. [...]

- Pois é isso, sêo Jeca, e daqui por diante não duvide mais do que a ciência disser.

- Nunca mais! Daqui por diante nha ciência está dizendo e Jeca está jurando em cima!

Tudo o que o doutor disse aconteceu direitinho! Três meses depois ninguém mais conhecia o Jeca. A ANKILOSTOMINA curou-o do Amarelão. O BIOTÔNICO deixou-o bonito, corado, forte como um touro. A preguiça desapareceu. Quando ele agarrava no machado, as árvores tremiam de pavor. [...]

E Jeca já não plantava rocinhas como antigamente. Só queria saber de roças grandes, cada vez maiores. [...]

E se alguém lhe perguntava: Mas para que tanta roça, homem?

Ele respondia: É que agora quero ficar rico [..] Quero mostrar a esta paulama quanto vale um homem que tomou remédio de Nha Ciência, que usa botina cantadeira e não bebe nem um só martelinho de cachaça. [...]

(LOBATO, 2014) 
O folheto circulou durante décadas no Brasil e em 1982 sua tiragem ultrapassou cem milhões de exemplares, sendo considerada a peça de maior sucesso da história da propaganda brasileira. Ancorada no discurso científico, a campanha acabou contribuindo para conscientizar a população no sentido de que tais comportamentos considerados negativos, longe de serem normais ou de constituírem traços inerentes à personalidade de alguém, deviam-se a uma doença que podia ser curada. E que, sem dúvida, era preciso fazê-lo. Assim, fomentou-se a crença de que, ao serem corretamente diagnosticadas e medicadas, as pessoas melhorariam suas vidas, sobretudo no que se refere à produtividade. É isso o que ressaltam Paulo Vaz e Daniel Portugal no artigo A felicidade é química e pode ser vendida (2012). Desde então, portanto, as indústrias farmacêuticas já desenvolviam estratégias persuasivas para recrutar clientes em potencial. Também naquela época, a ideia era fazer com que as pessoas se concebessem como doentes para, em seguida, oferecer-lhes uma cura.

No entanto, apesar das aparentes continuidades com relação às práticas acima narradas, há também algumas rupturas que podem ser significativas para compreender as dinâmicas contemporâneas. O conto de 1924 destaca a necessidade de corrigir um corpo indisciplinado, na época considerado não só algo muito negativo, mas que sobretudo denotava certa anormalidade. Essa intenção de propagar a disciplina no sentido de normalizar os cidadãos trabalhadores é algo que se percebe, inclusive, no recurso a personagens operários e camponeses, tanto no texto de Lobato quanto nas ilustrações que serão analisadas a seguir e que apontam numa direção semelhante. Isso se revela também na preocupação do autor por atingir, com esse almanaque, principalmente o público composto pelos mais pobres e pelas crianças, cujo caráter se considerava ainda em formação.

O sucesso da campanha do Biotônico em parceria com Lobato foi tão notável, que ela chegou a ser reproduzida em diversos anúncios publicitários veiculados nos jornais de maior circulação no país entre as décadas de 1930 e 40 [Figuras 2 e 3].

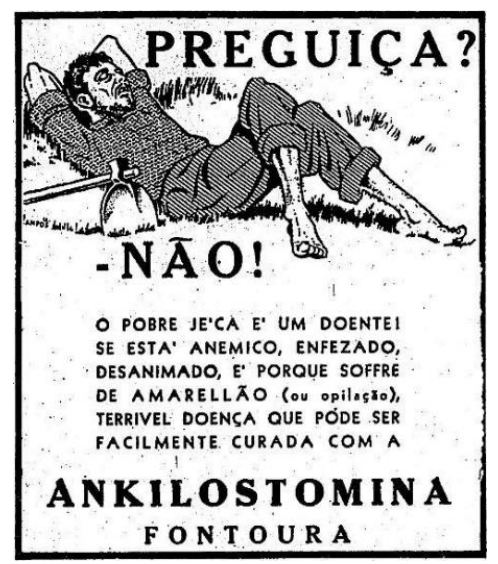

Fig.2. Estado de S. Paulo, 1934

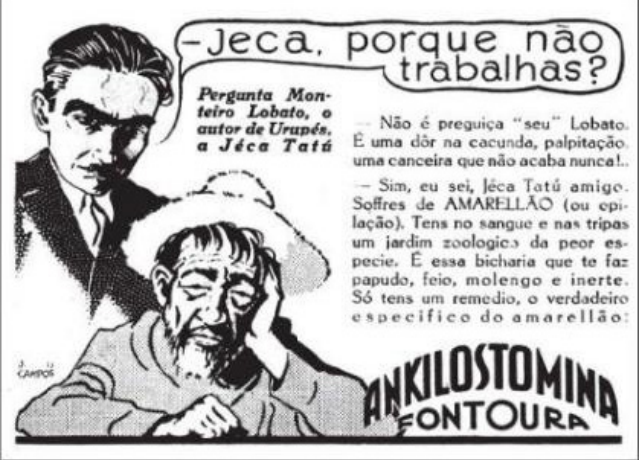

Fig. 3. Almanaque do Biotônico, 1935. 
Em 1936 foi publicado, no jornal Estado de S. Paulo, um anúncio do medicamento cujo título exclamava: "Imprestável para o trabalho!". Entretanto, essa peça não era mais protagonizada por Jeca Tatu, mas por um operário qualquer. Contudo, os comportamentos atribuídos ao célebre personagem continuavam sendo descritos como sintomas do amarelão, como mostra a Figura 4:

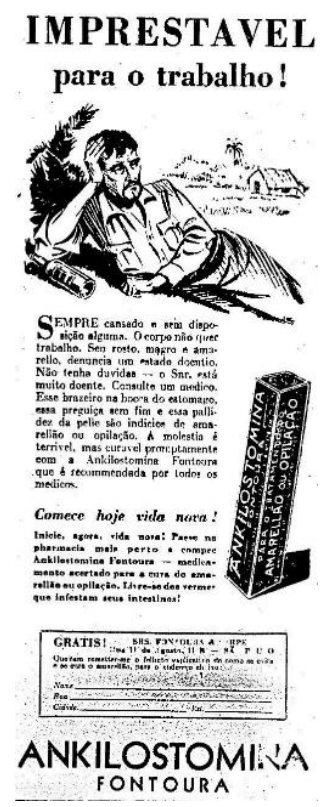

Fig.4. Estado de S. Paulo, 1936

O caso aqui enfocado constitui um bom exemplo do modo como as intervenções médicas e farmacológicas propostas naquela época tinham como fim a cura de patologias, muitas vezes identificadas como desvios de um modelo de funcionamento psicofísico considerado normal. Tratava-se, dessa maneira, de promover estratégias biopolíticas por meio de determinadas alterações nos estilos de vida, com o objetivo de enquadrar os sujeitos nas demandas produtivas de seu tempo. Isso incluía, sobretudo, o adestramento para que fossem eficazes no manejo das maquinarias fabris, formatando seus corpos e subjetividades para que pudessem realizar trabalhos mecânicos e serializados.

Com os avanços dessas estratégias biopolíticas, portanto, o que no início foi vivenciado como uma imposição ou um abuso de poder proveniente dos saberes médicos, acabou se introjetando nas subjetividades modernas. Aos poucos, os cidadãos passaram a clamar pela intervenção do Estado em seus corpos, com a reivindicação de políticas públicas que atentassem às suas vidas promovendo a saúde e evitando as doenças. Mas não foi um processo simples e linear: para que isso pudesse ocorrer - ou seja, para que 
os mecanismos disciplinadores e biopolíticos fossem assimilados pelas populações e tivessem sucesso - foi preciso propagar um conjunto de práticas, discursos e crenças, estimulando a produção de novas subjetividades compatíveis com aquele projeto de mundo. Um quadro que vigorou, sem que os conflitos e as resistências conseguissem abalá-lo, pelo menos até meados do século XX.

\section{Mercado, mídia e tecnociência}

A partir de 1960, porém, várias transformações se delinearam nas sociedades ocidentais. Com a crise do poder disciplinar e da ética protestante que o sustentara, assim como a emergência do neoliberalismo e a gradativa proliferação de uma certa ética empresarial, as redes de poder passaram a modular os corpos e as subjetividades de forma mais tênue (FOUCAULT, 1979), embora também mais intensa e sofisticada. Para efetivá-lo, foi desenvolvida uma complexa aparelhagem informática e digital, que facilitou a abrangência de toda a tessitura social em suas flexíveis e flutuantes malhas, não deixando praticamente nada de fora (DELEUZE, 1992). Um conjunto de novas práticas e saberes foi ganhando cada vez mais legitimidade e contribuiu para a crise das instituições de confinamento típicas das sociedades industriais, bem como das maquinarias mecânicas e analógicas que as sustentavam. Nessa transição, três pilares tornaram-se fundamentais para turbinar os horizontes biopolíticos assim renovados: o mercado, a mídia e a tecnociência.

Nesse novo regime de poder, que foi se constituindo nas últimas décadas, intensificou-se a ênfase do biopoder na vida de cada um, que se tornou um alvo prioritário de reflexão e ação. Mas ela deixou de ser conduzida pelos roteiros pré-determinados e pelas técnicas repressivas, verticalizadas e normalizadoras de adestramento disciplinar. Qualquer autoridade passou a ser questionável, as relações de pertencimento tornaram-se mutáveis e os sujeitos foram instados a viver de forma autônoma com a mira na realização individual e na alta performance em todos os campos (JORGE, 2014). Quando tais demandas resultam excessivas, os sujeitos contemporâneos encontram uma diversidade de soluções prontas à venda. Um exemplo é aquilo que Suely Rolnik (1997, p.19) denomina "kits de perfispadrão", que são ofertados de forma atraente pela mídia, seja por meio dos discursos publicitários ou nos gêneros jornalísticos e de ficção. Isso ocorre através de uma aliança tácita dos meios de comunicação com o mercado e com a tecnociência, sobretudo com as indústrias farmacêuticas. Por isso, esses três vetores se destacam ao atuarem em conjunto e com muita eficácia na atualidade, oferecendo uma diversidade de produtos e serviços que envolvem aconselhamentos, crenças e mitologias de época.

Com o declínio do plano transcendente no que concerne às explicações sobre a vida e o mundo, o discurso científico foi ganhando uma legitimidade crescente, sendo portador de uma verdade que hoje se considera quase inquestionável, contrariamente ao que ocorre com os preceitos religiosos, por exemplo. Esse solo facilitou a propagação 
das verdades produzidas pelas novas ciências da vida (entre elas, as neurociências), com apoio constante do mercado e da mídia. Esses discursos hoje invadem o cotidiano, fomentando e difundindo certas promessas no sentido de que a medicina tudo pode explicar e resolver - ou, então, tudo um dia poderá. Essas crenças penetram nas visões de cada um acerca de si mesmo e dos outros, estimulando novas práticas no cuidado de si e suscitando também formas inéditas de controle e assujeitamento.

Enquanto a sociedade disciplinar tinha como objetivo a produção de bons cidadãos, normalizando as eventuais patologias, aquilo que Gilles Deleuze (1992) nomeou sociedade de controle procura gerar ágeis consumidores. Assim, a ênfase sai da produção no modelo industrial e recai não apenas nos serviços mas, principalmente, no consumo e no marketing. Os indivíduos, por sua vez, já não parecem - e nem desejam - pertencer tanto a uma massa, mas passam a se tornar perfis que fazem parte de amostras mais ou menos voluntárias, quase sempre com finalidades mercadológicas. Com o progressivo desmantelamento do Estado de bem-estar social e com o alastramento do espírito empresarial em todas as instâncias, a biopolítica se desloca das medidas públicas que visam a todos os cidadãos e desliza para as mãos das corporações privadas. Através de novas modalidades tecnocientíficas e biotecnológicas - que atendem a diversos gostos, públicos e bolsos -, as empresas contemporâneas desempenham um papel fundamental na edificação e na manutenção vital dos corpos e das subjetividades.

Além disso, propaga-se a ideia de que cabe a cada indivíduo o papel não apenas de administrar as suas doenças (reais ou potenciais), como também de gerenciar, através de um controle contínuo, qualquer risco à sua saúde. Desse modo, procura-se não só evitar as patologias mas também se busca otimizar os próprios recursos psicofísicos. Nesse contexto se impõe o conceito de fator de risco, que faz da normalidade algo cada vez mais difícil de ser alcançado, chegando a perder seu sentido, uma vez que todo sujeito passa a se definir como doente em potencial. Isto é, alguém que precisa adaptar suas práticas cotidianas restringindo determinados prazeres e admitindo certos sofrimentos, de modo a reduzir suas probabilidades de adoecer.

Assim, a medicina que se limitava a tratar acidentes e doenças, agora aponta para a detectação e a administração de doenças crônicas, tendo como meta o controle e a otimização dos corpos. A manutenção da saúde tornou-se um vetor fundamental da autoadministração, graças a um conjunto de técnicas que vão de dietas e exercícios físicos até o consumo de produtos e serviços específicos. Nesse movimento, os indivíduos deixam de ser meros pacientes - como os definia a medicina moderna - para se tornarem consumidores ativos, sedentos por informações e técnicas que possibilitem a auto-prevenção e um cobiçado controle sobre a sua saúde.

\section{Reprogramar o corpo para aumentar a performance}

Aproveitando-se desse importante nicho de mercado que se formou em anos recentes, bem como da privatização das biopolíticas, as mídias em geral vêm incorporando 
em suas pautas muitas matérias voltadas à saúde. Essas reportagens podem ser consideradas peças publicitárias, visto que incitam os sujeitos a se conceberem como doentes e, em decorrência disso, a consumirem produtos e serviços medicamentosos (VAZ, 2012). $\mathrm{Na}$ televisão, por exemplo, valendo-se do entretenimento e de tons entusiásticos, tais programas atuam no intuito de nortear os espectadores nesse sentido, apresentando variados riscos que ameaçam a vida humana e oferecendo soluções para evitá-los ou contorná-los. Tudo isso se efetua através de discursos cientificistas que são endossados e legitimados pelos depoimentos de especialistas. Além disso, oferecem-se exemplos edificantes de pessoas que se encontravam no estado considerado negativo à luz dessas crenças e que, no entanto, conseguiram superá-lo graças a algumas mudanças implementadas em seus hábitos.

Na televisão brasileira da primeira e segunda década do século XXI, destacam-se: o programa diário intitulado Bem-estar, da TV Globo; os quadros do famoso médico Drauzio Varella, no Fantástico, da mesma emissora, e o reality-show Até quando você quer viver?, da emissora GNT. Este último enfoca o estilo de vida considerado pouco saudável dos participantes, calculando quanto tempo mais eles viverão se mantiverem seus hábitos. Assim, propondo uma série de mudanças - pautadas numa rigorosa dieta alimentar e na realização de exercícios físicos -, o programa acompanha as transformações dos participantes em suas novas atitudes, recalculando suas expectativas de vida. A intenção é demonstrar que determinadas privações e certos sofrimentos no dia a dia podem ser muito positivos, porque impactam não apenas a longevidade, mas principalmente a conquista de outro conjunto de atributos igualmente valorizados na atual cultura globalizada.

Essas manifestações midiáticas reforçam a legitimidade do saber científico e multiplicam as crenças apoiadas em sua eficácia, além de promoverem o perfil ideal que se deve almejar para si e que todos deveriam tentar conquistar, sugerindo que o bem-estar e a alta performance produtiva estão disponíveis para todos os que lutarem por isso. As mesmas reportagens costumam reprovar e tratar como desviantes aqueles sujeitos cujas condutas ou aparências não se enquadram nos valores vigentes, confirmando a necessidade de mudar.

Além desses programas pautados na saúde e no bem-estar, há muitas matérias jornalísticas - disponibilizadas também na internet - que apresentam informações sobre doenças, oferecendo aos leitores os medicamentos capazes de solucionar tais problemas. Ao se defrontarem com essas informações, os sujeitos vão incorporando os vocabulários científicos na linguagem coloquial, e se sentem aptos a prescrever seus próprios diagnósticos ou aconselhar os demais. As clínicas e os profissionais da saúde tornam-se, assim, apenas mais um tipo de intermediários para o cuidado de si. Outra de suas funções é a de se converterem em meras fontes para conseguir receitas de medicamentos controlados pelo Estado. Estes, no entanto, se tornam cada vez mais familiares para os consumidores, seja no intuito de tratar possíveis patologias ou para otimizar o desempenho produtivo. 
Como resultado dessa perda dos antigos monopólios, a medicina precisa se reinventar constantemente, ampliando suas áreas de atuação e inebriando-se também por uma perspectiva biologicista que é compatível com as novas tendências de controle e reprogramação corporal (SIBILIA, 2015). Trata-se agora de uma tecnomedicina, como a qualifica Nikolas Rose (2013), cuja credibilidade se tornou dependente de sofisticados equipamentos para o diagnóstico e os tratamentos. Nos Estados Unidos, por exemplo, de acordo com uma matéria publicada na revista Galileu em julho de 2014, os pacientes do grupo Carolinas HealthCare System são rigidamente monitorados através das compras de seus cartões de crédito. As informações são obtidas por mineradores de dados que analisam os hábitos de consumo dos usuários para diagnosticar aqueles que estão sujeitos a riscos, antes mesmo que as doenças se manifestem - e sem garantias de que elas venham, de fato, a se manifestar. Segundo um dos diretivos dessas clínicas, tais dados são muito mais eficientes do que aqueles que se obtêm nas consultas médicas. "Por exemplo, se um paciente com asma chega no Pronto Socorro, é possível acessar a ficha dele e descobrir se está comprando os remédios que deve corretamente, se consumiu cigarros ou se vive em uma área com muito pólen" (GALILEU, 2014).

É importante destacar que esses novos mecanismos de controle não ocorrem por imposição de instâncias de vigilância centralizadas, como acontecia nas sociedades disciplinares, mas por livre vontade dos indivíduos que - inseridos nas novas modalidades biopolíticas - dão o seu consentimento para que esse tipo de rastreio seja feito em benefício de suas saúde e segurança. Trata-se de serviços privados, destinados a um público-alvo específico; ou seja, àqueles que têm condições financeiras de pagar por ele e que o escolhem livremente. Mas a responsabilização dos sujeitos por suas ações é ainda maior que no contexto disciplinar, visto que o futuro de cada um se torna calculável e dependente das próprias condutas com base no autoexame para o constante autoaprimoramento.

A biopolítica, portanto, não mais se limita a agir nos polos saúde e doença, sem ter mais como foco a eliminação de patologias com o intuito de corrigir os cidadãos que se distanciam da normalidade. No final do século XX, ela foi absorvida pelo espírito empresarial e pela lógica do mercado, na tentativa de ampliar, controlar e remodelar as capacidades vitais dos sujeitos. Estas são concebidas agora como biocapitais, que devem ser lucrativas e bem cotadas nos flutuantes mercados em que seus portadores atuam. A finalidade consiste em otimizar a vida, sempre de acordo com os valores ora vigentes, e adaptá-la ao que cada um quer ser ou se espera que deveria ser.

Para que tudo isso seja viável, foram cruciais as transformações ocorridas no ramo da psiquiatra e das neurociências, bem como a crescente participação das indústrias farmacêuticas nos atuais modos de ser e viver, todas tendências alinhadas com a nova ética empresarial. Esses valores marcaram o ritmo para que tais demandas e transformações históricas pudessem acontecer, instaurando-se como o pano de fundo e a inspiração para o aprimoramento, gerenciamento e otimização das performances, da autoestima e 
do bem-estar, bem como a superação constante dos limites e a eliminação de todo e qualquer dissabor cotidiano. Em suma, todas premissas fundamentais deste novo regime de poder.

A medicalização aparece, assim, de forma naturalizada no cotidiano dos sujeitos contemporâneos, que procuram otimizar seus desempenhos em todos os âmbitos para atingirem os ideais de bem-estar, sucesso, felicidade e produtividade hoje em vigor. Como exemplo, cabe citar a campanha do medicamento de venda livre Neosaldina, veiculada em 2005 nas ruas das principais capitais brasileiras, cujo mote era o seguinte: "Não leve dor de cabeça. Leve Neosaldina". Em prol de uma vida sem problemas, o medicamento se oferecia como um elixir contra as pressões mais banais do dia-a-dia, tais como: contas a pagar, boletim escolar, reuniões, imposto de renda e falta de fundos no banco [Figuras 5, 6, 7 e 8]. Há também os anúncios do analgésico Advil, veiculados na fanpage desse medicamento na rede social Facebook, entre 2013 e 2015, enfatizando a necessidade de um corpo sempre apto a todas as demandas, como mostram as Figuras 9, 10, 11 e 12.

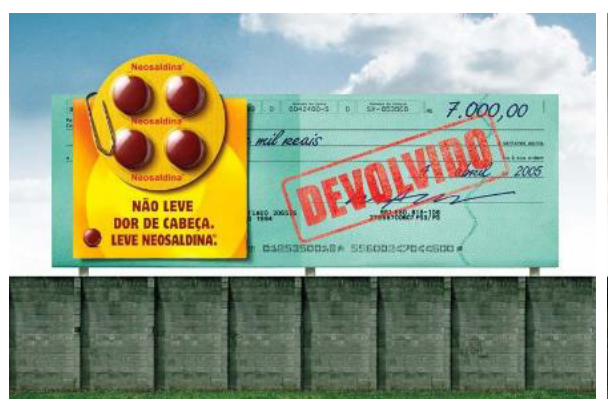

Fig.5

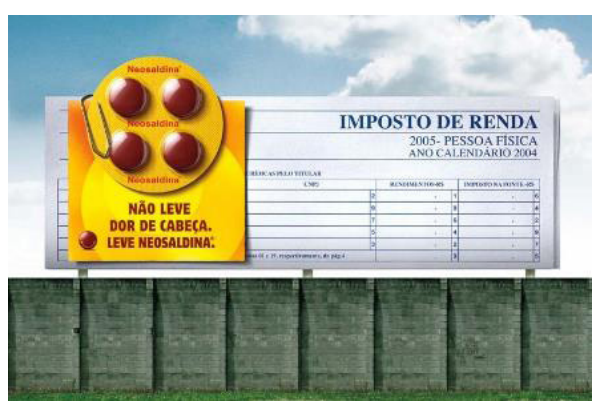

Fig.7

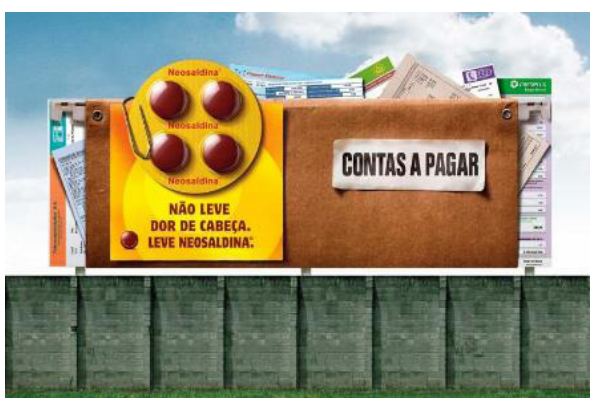

Fig.6

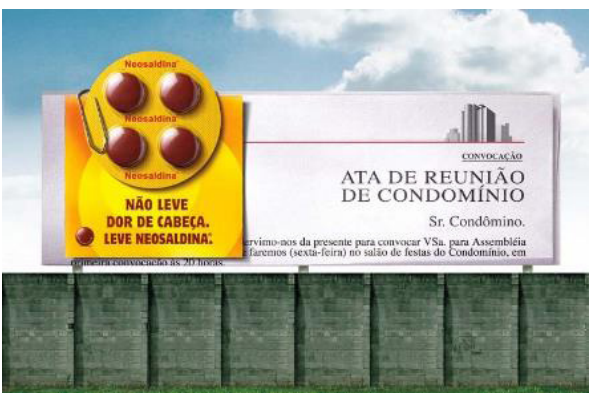

Fig.8 


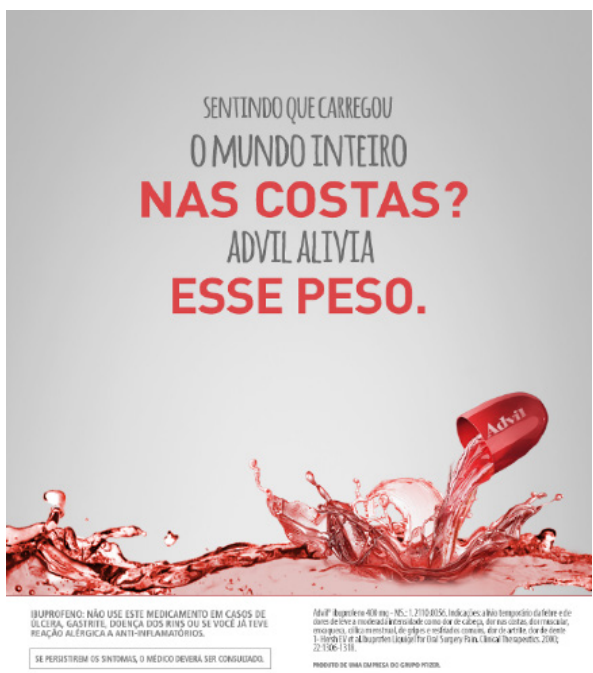

Fig.9

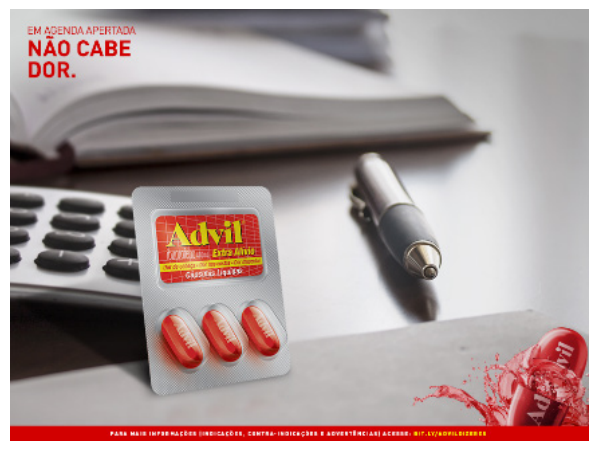

Fig.11

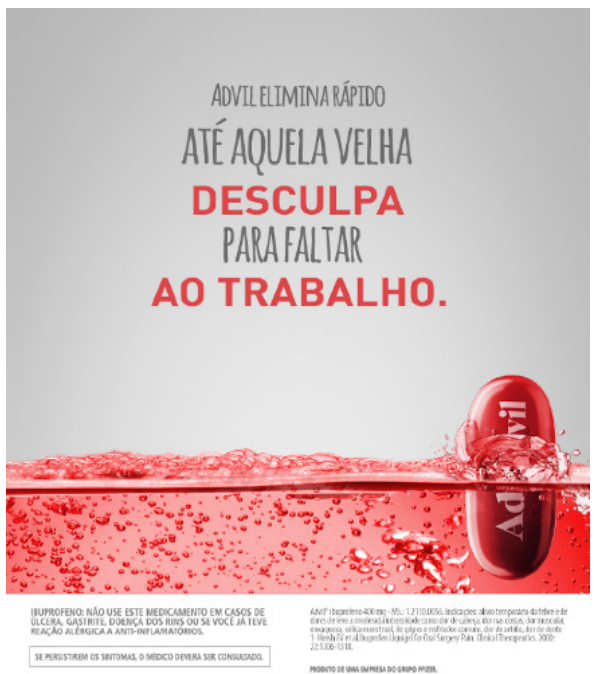

Fig.10

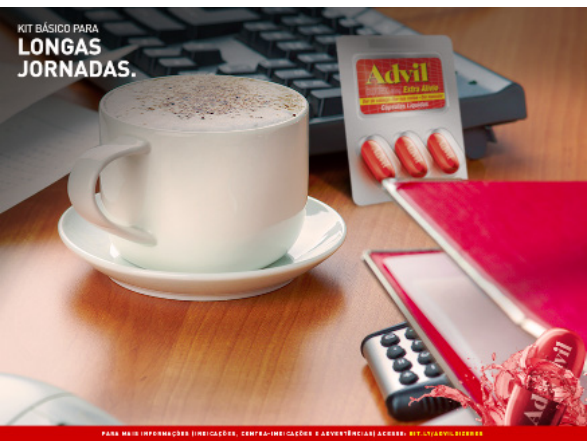

Fig.12

\section{Deslocamentos nas concepções sobre a vida}

Até meados da década de 1970, sabe-se que a psiquiatria agia conforme os preceitos disciplinares, visando a excluir os desviantes, afastando-os do convívio social para tentar adequá-los à norma vigente em instituições específicas. Agora, com as transformações que geraram novas torções no capitalismo e na própria psiquiatria, há uma tentativa de inclusão sem precedentes. A prática psiquiátrica deixou de se restringir a tratar um sofrimento e passou a promover a saúde, a felicidade e o bem-estar, através de um aprimoramento psicofísico sem pausa e para todos. Nessa ambição de incluir a totalidade da população em seus projetos de intervenção e regulação, a psiquiatria se desfaz da velha "ideia 
de precariedade, imprevisibilidade, oscilação, inerente à vida bem vivida, em prol de um duvidoso ideal normativo de performance otimizada" (BEZERRA, 2016, p. 23). Por isso, os que recebem as intervenções médicas e farmacológicas são consumidores que têm acesso a uma gama de técnicas de otimização, cujas escolhas se baseiam em "desejos que parecem triviais, narcisísticos ou irracionais, modelados não por necessidade médica, mas pela cultura do mercado e pelo consumo" (ROSE, 2013, p. 37). Redefinem-se, assim, as velhas fronteiras entre o normal e o patológico.

Até meados do século XX, com as fortes influências da fenomenologia e da psicanálise, os sujeitos modernos costumavam se compreender e se auto-avaliar norteados pela crença de que suas essências habitavam um misterioso espaço etéreo localizado em seu interior. Essa profundeza psicológica guardava tanto a fonte dos desejos como a raiz secreta dos sofrimentos. Por isso, cabia a cada um desvendar essa complexa entidade, por meio do mergulho simbólico nas próprias entranhas que se realizava através de práticas como psicoterapias, introspecção, confissões, leituras silenciosas e escrita de si, sempre privilegiando o silêncio e a solidão ou o diálogo intimista. A psicanálise, nessa fase, era fundada numa terapia analítica pautada na concepção de que os sofrimentos psíquicos partiam de um conflito, um enigma a ser decifrado que se supunha decorrente da experiência individual e singular de cada sujeito com o meio em que vivia. Tratar um sintoma era tentar compreender - através das narrativas de seu protagonista - o que levou o indivíduo àquele sofrimento, procurando elaborar suas complexidades que, em última instância, supunha-se que eram misteriosas por definição.

Com as descobertas ocorridas no campo das neurociências, em sintonia com certas redefinições na psiquiatria - com a publicação do DSM-III, em 1980 -, novos saberes, poderes e verdades foram se configurando. Essas transformações incluem certo declínio das concepções do sujeito da ação até então vigentes, e das narrativas a ele associadas que se pautavam em justificativas simbólicas. Foi abalada aquela dimensão experiencial do sofrimento. Ao mesmo tempo, possibilitou-se a proliferação dos diagnósticos clínicos com aval científico nesse campo, bem como uma enorme ampliação nas possibilidades de intervenção e medicação dos processos vitais. Isso foi possível porque as ciências neurológicas e comportamentais ofereceram outras explicações acerca de como conduzimos nossas vidas e configuramos o que somos, deslocando-nos de um eu psicológico para um eu neurológico ou uma individualidade somática (ROSE, 2013).

Em 1953, uma grande descoberta contribuiu para delinear tais transformações: a estrutura da molécula de DNA. Com essa conquista, o enigma da vida começava a ser decifrado. Tratava-se de informação, texto codificado e inscrito num suporte biológico. Tal perspectiva deu lugar a uma impactante constatação: já que a vida é informação e se baseia nas instruções expressas nos códigos genéticos, seria possível realizar alterações nesses dados com a finalidade de manipular os componentes indesejáveis de cada corpo e reprogramá-los visando a alcançar efeitos específicos. Graças a essa possibilidade inédita 
de reprogramação genética - bem como celular ou mesmo cerebral - a tecnociência agora não aponta apenas para a possibilidade de correção dos erros da estrutura humana com vistas a normalizá-la. Neste novo quadro, a meta passou a ser a otimização dos desempenhos e o aprimoramento de qualquer falha que comprometa o bem-estar ou a performance produtiva de cada um.

A compreensão acerca do mundo, de nós mesmos e dos outros passou a se inscrever na biologia humana: nas moléculas, nos genes, nas células, nos hormônios e nos neurotransmissores que nos compõem. O âmago do que somos não parece mais residir na alma ou na misteriosa essência interior, onde se acreditava que habitava a singularidade dos sujeitos modernos, mas em partículas físicas como o material genético de cada um ou naquilo que informa sua composição biológica. Embora permaneça oculto dentro de cada um, tudo isso torna-se cada vez mais visível, objetivável e digitalizável através dos aparelhos de visualização e imageamento corporal. Graças à crescente compatibilidade dos corpos humanos com esses artefatos, tais entranhas carnais são convertidas em informações codificadas que tendem a ser, não somente observadas e diagnosticadas, mas também, gradativamente, manipuladas.

Uma das consequências desse desenvolvimento da aparelhagem digital neurocientífica foi a popularização de imagens e informações que associam a atividade cerebral a quase todos os aspectos da vida. Ecoando essas pesquisas e descobertas, a mídia contribuiu para fomentar uma percepção do cérebro como autor das ações que definem o que é ser alguém. As explicações acerca do bem-estar psicofísico (ou do conseguinte mal-estar) passaram a se associar ao funcionamento cerebral. Tornou-se habitual, por exemplo, que a mídia e os próprios indivíduos ressaltem a importância de praticar exercícios físicos para aliviar o estresse ou a ansiedade, bem como para se tornarem mais produtivos, já que nesses esforços o cérebro induz a liberação de neurotransmissores como a endorfina, a dopamina e a serotonina, provocando sensações de disposição e felicidade. Algo comparável ocorre com as explicações acerca dos efeitos da alimentação e do uso de medicamentos, bem como das próprias condutas e variações de humor, que agora costumam ser justificadas como efeitos de alterações na química cerebral. A tendência é esvaziar qualquer associação com o simbólico, voltado para uma experiência singular e pessoal que deve ser interpretada, dando lugar a explicações de cunho fisicalista e biológico que induzem a tratamentos medicinais.

Percebe-se, portanto, uma tendência à redução de toda a experiência humana à materialidade de um corpo cientificamente objetivável. Isso faz com que compreendamos as variações de nossos humores, pensamentos, sentimentos e vontades recorrendo a explicações biológicas, sobretudo neuroquímicas, conforme se constata num anúncio do antidepressivo Prozac veiculado nos Estados Unidos no final dos anos 1990 [Figura 13]: 


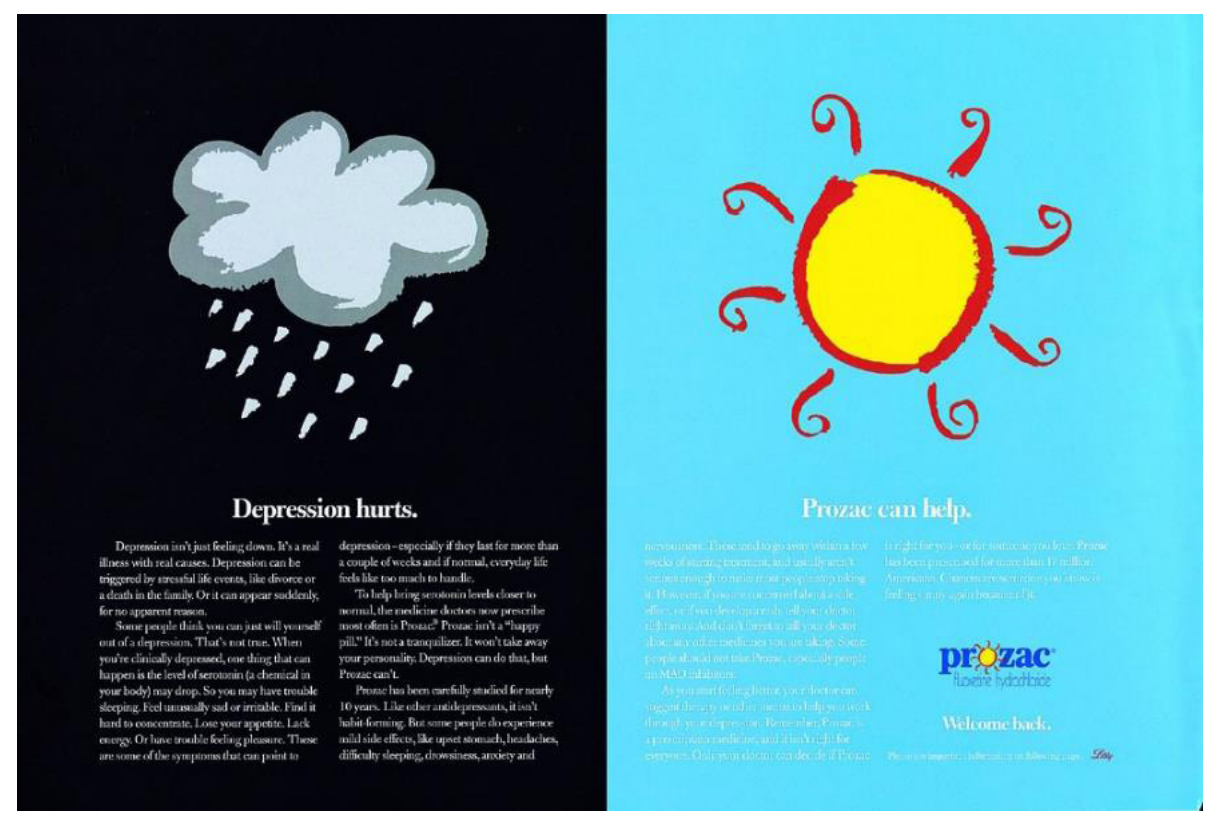

Fig 13

\section{Considerações finais}

Nos discursos aqui estudados, observa-se a presença de certo mito cientificista, bastante recorrente em publicidades e reportagens dos meios de comunicação contemporâneos. Explicações de cunho técnico são utilizadas na apresentação de um produto ou serviço recém-descoberto, que promete desvendar e explicar os mistérios da natureza orgânica corporal, além de solucionar algum tipo de conflito demasiadamente humano, mantendo sob controle seus possíveis efeitos nocivos no comportamento do sujeito em questão - e, em particular, na sua produtividade. Assim, o mito cientificista é alimentado por um conjunto de crenças e valores que se apoiam na legitimidade do saber científico, visando a produzir saberes com efeito de verdade - algo muito bem cotado num ambiente cultural que destronou todas as certezas, sobretudo as mais transcendentes. Essas estratégias, porém, costumam atender aos interesses do capitalismo e do consumismo em geral, e, em particular, das indústrias farmacêuticas.

Fundamental na sustentação do atual regime de poder, a mitologia cientificista se ancora numa racionalidade instrumental que é própria da ética empresarial, expandindo a lógica do cálculo, da técnica e das soluções farmacológicas para todos os âmbitos, apresentando-se como a única fonte de verdade e a consequente solução para todos os problemas. Há, portanto, na cultura globalizada do início do século XXI, uma quase 
indiscutida valorização das pesquisas científicas - e, portanto, das reportagens midiáticas que as divulgam, bem como das possibilidades de conversão de seus resultados em mercadorias - que privilegiam determinados modelos de conduta e pensamento. Isso se produz em detrimento de outras fontes de sentido - inclusive no que se refere à saúde, às doenças, ao bem-estar ou ao mal-estar -, que são desqualificadas ou silenciadas por não se adequarem ao projeto de mundo dominante e às subjetividades que por ele são estimuladas.

Por isso, todo um conjunto de aflições e comportamentos que, até meados do século $X X$, eram vistos como condições naturais da vida humana ou como características pessoais inerentes a determinado indivíduo, nas últimas décadas têm se reduzido a explicações de cunho biológico. E, em consequência, estão se transformando em patologias ou transtornos que precisam ser tratados com substâncias farmacológicas. Disso decorre uma neutralização das diferenças entre as diversas experiências subjetivas, sendo rotulado como patológico qualquer comportamento que seja considerado falho com relação às exigências do sistema de produção atual. Isso torna as doenças mentais não mais uma exceção ou um raro desvio da norma, mas uma propensão na qual toda a população tem o risco de cair. E, por isso, entende-se que deve ser medicalizada.

Paula Sibilia é professora do Programa de Pós-Graduação em Comunicação (PPGCOM) e do Departamento de Estudos Culturais e Mídia da Universidade Federal Fluminense.

paulasibilia@gmail.com

Marianna Ferreira Jorge é doutoranda em Comunicação na Universidade Federal Fluminense e bolsista da Capes.

mariannaferreirajorge@gmail.com

\section{Referências}

BEZERRA, B. Haverá condições que fermentarão transformações profundas. Entrevista de Benilton Bezerra por Paula Sibilia. In: 50 anos da história da loucura. RJ: 2016 (no prelo).

DELEUZE, G. Conversações. Rio de Janeiro: Editora 34, 1992.

FOUCAULT, M. A história da sexualidade: A vontade de saber, v. 1. Rio de Janeiro: Graal, 2012. Poder-Corpo. In: Microfísica do poder. Rio de Janeiro, Graal, 1979.

GALILEU. "Hospitais americanos usam dados de cartões de crédito para prever quem vai ficar doente". Revista Galileu, 2014. Disponível em: http://revistagalileu.globo.com/Tecnologia/noticia/2014/07/ hospitais-americanos-usam-dados-de-cartoes-de-credito-para-prever-quem-vai-ficar-doente.html. Acesso em: 10 de julho de 2014. 
JORGE, M. F. Desempenho tarja preta: medicalização da vida e espírito empresarial na sociedade contemporânea. 2014. Dissertação (Mestrado em Comunicação) - Programa de Pós-Graduação em Comunicação. Universidade Federal Fluminense, Niterói, RJ.

LOBATO, M. Jeca Tatu. Globo.com, 2014. Disponível em: <http://lobato.globo.com/misc_jeca.asp> Acesso em: 25 de junho de 2014.

PALMA, A. "Monteiro Lobato e a origem de Jeca Tatu". In: Invivo Fiocruz, 2014. Disponível em: http://www.invivo.fiocruz.br/cgi/cgilua.exe/sys/start.htm? UserActiveTemplate=espanol\&infoid=103 $5 \&$ sid=7. Acesso em: 25 de junho de 2014.

ROLNIK, S. Toxicômanos da identidade: subjetividade em tempo de globalização. In: LINS, D. (org.). Cultura e Subjetividade: saberes nômades. Campinas, SP: Papirus Editora, 1997.

ROSE, N. A política da própria vida: biomedicina, poder e subjetividade no século XXI. São Paulo: Paulus, 2013.

SIBILIA, P. O homem pós-orgânico: A alquimia dos corpos e das almas à luz das tecnologias digitais. Rio de. Janeiro: Contraponto, 2015.

VAZ, P. Doenças mentais e consumo nas revistas semanais brasileiras. E-compós, Brasília, v.15, n.1, 2012. VAZ, P.; PORTUGAL, D. "A felicidade é química e pode ser vendida?" Anais do XXI Encontro Anual da Compós, Juiz de Fora, 2012.

Artigo recebido em dezembro de 2015 e aprovado em março de 2016. 